\title{
Lembaga Penyelesaian Sengketa Adat Laut "Panglima Laôt" di Aceh sebagai Bentuk Pengembangan Alternatif Penyelesaian Sengketa dalam Sistem Hukum di Indonesia
}

\begin{abstract}
Sri Walny Rahayu ${ }^{24}$
Abstrak

Pengelolaan hasil laut dan perikanan di Indonesia rentan memunculkan sengketa karena laut bersifat open access. Dalam lingkup lokal, Provinsi Aceh memiliki lembaga alternatif penyelesaian sengketa (APS) adat laut yakni Panglima Laôt. Penyelesaian sengketa di luar pengadilan sebelumnya telah diatur dalam Undang-Undang Nomor 30 Tahun 1999 tentang Arbitrase dan APS (UU APS). Namun, sistem pendukung dari UU APS ini belum terbentuk sehingga penyelesaian sengketa melalui jalur alternatif seperti lembaga APS adat laut Panglima Laôt tidak berjalan secara optimal sekalipun putusannya bersifat mengikat bagi para pihak.
\end{abstract}

Kata Kunci: lembaga penyelesaian sengketa adat laut, Panglima Laôt, alternatif penyelesaian sengketa, sistem hukum Indonesia, sistem pendukung.

\section{"Panglima Laôt" as Traditional (adat) Dispute Resolution in Aceh as an Alternative Dispute Resolution in Indonesian Legal System}

\begin{abstract}
The nature of the sea as an open access area potentially created a dispute especially concerning the management of marine and fisheries products. Locally, Aceh Province has established a traditional law of the sea Alternative Dispute Resolution (ADR) body or so-called "Panglima Laôt". Formerly, ADR has been regulated by the Law number 30 year 1999 concerning Arbitration and ADR. However, the supporting system of this regulation has not been created yet. That leads to inconsistency and ineffectiveness of the mechanism through ADR body "Panglima Laôt", even though its decisions binding and applied to all parties.
\end{abstract}

Keywords: 'Adat' dispute resolution body, Panglima Laôt, alternative dispute resolution, Indonesian legal system, support system.

\section{A. Pendahuluan}

Indonesia adalah negara kepulauan yang memiliki potensi hasil kelautan dan perikanan yang sangat besar dan beragam. Aktualisasinya dirumuskan dalam

24 Dosen Fakultas Hukum Universitas Syiah Kuala Darussalam, Jl. Putroe Phang Darussalam, Banda Aceh, ayoe_armans@yahoo.com, S.H. (Universitas Syiah Kuala), M.H. (Universitas Padjadjaran), Dr. (Universitas Padjadjaran). 
Sri Walny Rahayu: Lembaga Penyelesaian Sengketa Adat Laut "Panglima Laôt" di Aceh sebagai Bentuk Pengembangan Alternatif Penyelesaian Sengketa dalam Sistem Hukum di Indonesia

kebijakan pembangunan Indonesia di era reformasi yang mengenalkan dan mengadopsi arti penting pengakuan dan perlindungan hukum nasional terhadap masyarakat hukum adat berikut kearifan lokalnya. ${ }^{1}$ Dalam hal ini, pembangunan Indonesia berbasis kepentingan, pengetahuan dan cara-cara yang dimiliki masyarakat lokal berdasarkan pengetahuan dan kearifan lokal dalam mengelola lingkungannya.

Sumber daya laut yang bersifat open access berpotensi menimbulkan sengketa antara lembaga penyelesaian sengketa adat laut yang memiliki hak ulayat laut bersifat komunal (common property) dengan pihak nelayan modern atau pelaku usaha penangkapan ikan yang menggunakan armada penangkapan, alat serta teknologi yang tidak ramah lingkungan. Hal tersebut menimbulkan rusaknya sumber daya alam laut dan pesisir. Menurunnya daya dukung sumber daya dan dalam jangka panjang mengakibatkan suatu tragedi bersama (open tragedy) seperti munculnya berbagai bentuk bencana alam.

Undang-Undang Nomor 45 Tahun 2009 tentang Perubahan atas Undang-Undang Nomor 31 Tahun 2004 tentang Perikanan (selanjutnya disebut UU Perikanan Tahun 2009) dibentuk untuk mengendalikan usaha perikanan melalui pengaturan pengelolaan perikanan serta tindakan penegakan hukum baik oleh aparat hukum maupun aparat berwenang lainnya. ${ }^{2}$ Pengadilan Negeri Medan merupakan satusatunya lembaga yang berwenang menangani pelanggaran perikanan di Pulau Sumatera. Namun keberadaannya di Indonesia khususnya di Sumatera ternyata belum cukup efektif. ${ }^{3}$

Pengadilan Perikanan di bawah Pengadilan Negeri Medan, terealisasi tahun 2012 setelah sembilan tahun terbentuknya UU Perikanan di Indonesia sejak pertama dibentuk pada tahun 2004. Kendala lainnya adalah aparat penegak hukum belum siap menjalankan tugasnya karena faktor kurangnya jumlah aparat penegak hukum di lingkungan pengadilan, kemampuan hakim masih kurang memadai, padahal dibutuhkan keahlian khusus di bidang perikanan terutama yang berkaitan aspek teknis perikanan, alat tangkap, dan lainnya. ${ }^{4}$ Akhirnya penyelesaian masalah

1 DPR sedang membahas RUU tentang Pengakuan dan Perlindungan Hak Masyarakat Hukum Adat.

2 Pasal 71 ayat (1) - ayat (4) UU Perikanan Tahun 2009 menyatakan bahwa dibentuk pengadilan perikanan yang berwenang memeriksa, mengadili, dan memutus tindak pidana di bidang perikanan. Pengadilan perikanan tersebut merupakan pengadilan khusus yang berada dalam lingkungan peradilan umum. Pengadilan perikanan dibentuk di Pengadilan Negeri Jakarta Utara, Medan, Pontianak, Bitung, dan Tual. Pengadilan perikanan sebagaimana dimaksud berkedudukan di pengadilan negeri.

3 Hukum Online, "Pengadilan Perikanan Belum Efektif", http://www.hukumonline.com/berita/baca/hol21242/pengadilan-perikanan-belum-efektif, diakses pada 11 April 2013.

4 Maria Maya Lestari, "Penegakan Hukum Pidana Perikanan di Indonesia Studi Kasus Pengadilan Negeri Medan", Jurnal I I m u H kum, Vol. $3 \mathrm{No} .2 \mathrm{Tahun} 2013$, h I m. $289-292$, http://www.ejournal.unri.ac.id/index.php/JlH/article/view/1822.html, diakses pada 11 Februari 2013. 
Sri Walny Rahayu: Lembaga Penyelesaian Sengketa Adat Laut "Panglima Laôt" di Aceh sebagai Bentuk Pengembangan Alternatif Penyelesaian Sengketa dalam Sistem Hukum di Indonesia

perikanan menjadi sama dengan kasus-kasus pada pengadilan perdata pada umumnya.

Indonesia membentuk Undang-Undang Nomor 30 Tahun 1999 tentang Arbitrase dan Alternatif Penyelesaian Sengketa (UU APS). Pembentukan UU tersebut sebagai jawaban terhadap kebutuhan bisnis yang bergerak cepat dan mengurangi tumpukan kasus di peradilan perdata. APS merupakan terjemahan dari Alternative Dispute Resolution (ADR). Konsep penyelesaian sengketa ADR berakar dari sistem pengaturan sendiri (self-governing system), yang secara sederhana bukan merupakan hal baru, telah lama dipraktikkan dan memiliki persamaan dengan konsep mekanisme penyelesaian sengketa adat melalui peradilan adat.

Filosofi pembentukan UU APS adalah kebutuhan penyelesaian sengketa di luar peradilan perdata secara cepat, murah, putusan dihasilkan melalui cara musyawarah, tidak ada penggugat dan tergugat, serta menghasilkan win-win solution. Kenyataannya, APS hanya diatur dalam tiga pasal dari 82 pasal, sedangkan 79 pasal lainnya mengatur mengenai arbitrase. UU tersebut menjelaskan APS secara sumir (satu alinea saja).

Konsep pembangunan nasional yang berkeadilan berasal dari nilai-nilai Pancasila yang diturunkan dalam Pasal 18B ayat (1) UUD 1945 Perubahan Kedua Tahun 2000. Ruhnya diaktualisasikan ke dalam Undang-Undang Nomor 22 Tahun 1999 tentang Pemerintahan Daerah (selanjutnya UU Pemda Tahun 1999) yang mencabut UndangUndang Nomor 5 Tahun 1974 tentang Pemerintahan Daerah (selanjutnya UU Pemda Tahun 1974). ${ }^{5}$ UU Pemda Tahun 1999 memberikan otoritas kepada pemerintah di daerah untuk mengatur rumah tangganya sendiri. Masyarakat adat beserta hakhaknya kembali mendapatkan pengakuan hukum di Indonesia. UU Pemda Tahun 1999, dicabut oleh Undang-Undang Nomor 32 Tahun 2004 tentang Pemerintahan Daerah (Selanjutnya UU Pemda Tahun 2004). ${ }^{6}$

Pasal 18B ayat (2) UUD 1945 mengakui persekutuan hukum masyarakat adat sebagai identitas budaya beserta hak tradisionalnya dihormati sejalan dengan perkembangan zaman dan peradaban, sepanjang masih hidup dan sesuai dengan perkembangan masyarakat dan prinsip NKRI yang diatur undang-undang. Namun, sampai saat ini UU sebagaimana dimaksud Pasal 18B ayat (2) UUD 1945 belum diwujudkan. Sekalipun pengaturannya secara parsial ditemukan dalam Pasal 97

5 Sejarah Indonesia mencatat, aneka ragam bentuk persekutuan hukum masyarakat adat di Indonesia, pernah dihilangkan dan diseragamkan dengan desa melalui UU Pemda Tahun 1974. Hal tersebut menyebabkan hilangnya persekutuan masyarakat adat dan hak-hak tradisional yang memiliki corak beragam.

6 UU Pemda Tahun 2004 diubah dengan Perpu No. 3 Tahun 2005 tentang Perubahan atas Undang-Undang No. 32 Tahun 2004 tentang Pemerintahan Daerah (LN RI Tahun 2005 Nomor 38, TLN RI Nomor 4493). Perpu No. 3 Tahun 2005 menjadi Undang-Undang No. 8 Tahun 2005 (LN RI Tahun 2005 Nomor 108, TLN RI No. 4548). UU No. 8 Tahun 2005 yang merupakan perubahan pertama diubah kembali oleh UU Nomor 12 Tahun 2008 merupakan perubahan kedua atas UU Pemda Tahun 2004. 
Sri Walny Rahayu: Lembaga Penyelesaian Sengketa Adat Laut "Panglima Laôt" di Aceh sebagai Bentuk Pengembangan Alternatif Penyelesaian Sengketa dalam Sistem Hukum di Indonesia

Undang-Undang Nomor 6 Tahun 2014 tentang Desa (UU Desa Tahun 2014), yang diundangkan tanggal 15 Januari 201 jo. Pasal 1 ayat (33) dan Pasal 22 Undang-Undang Nomor 1 Tahun 2014 tentang Perubahan atas Undang-Undang Nomor 27 Tahun 2007 tentang Pengelolaan Wilayah Pesisir dan Pulau-pulau Kecil (UU No. 1 Tahun 2014). ${ }^{7}$ Adapun Pasal 28I ayat (3) UUD 1945 yang terdapat dalam Undang-Undang Nomor 39 Tahun 1999 tentang Hak Asasi Manusia (selanjutnya UU HAM Tahun 1999), yang diatur dalam satu pasal yaitu Pasal 6 ayat (1) dan (2).

Provinsi Aceh ${ }^{8}$ menindaklanjuti Pasal 18B ayat (1) UUD 1945, dengan membentuk Undang-Undang Nomor 44 Tahun 1999 tentang Penyelenggaraan Keistimewaaan Provinsi Daerah Istimewa (selanjutnya UU Penyelenggaraan Keistimewaaan Provinsi Daerah Istimewa Tahun 1999)..$^{9}$ Selanjutnya dibentuk Undang-Undang Nomor 18 Tahun 2001 tentang Otonomi Khusus bagi Daerah Istimewa Aceh sebagai Provinsi Nanggroe Aceh Darussalam, yang dicabut oleh Undang-Undang Nomor 11 Tahun 2006 tentang Pemerintahan Aceh (UU Pemerintahan Aceh Tahun 2006). ${ }^{10}$

7 Pasal 1 ayat (33) UU No. 1 Tahun 2014 menyebutkan "Masyarakat Hukum Adat adalah sekelompok orang yang secara turun-temurun bermukim di wilayah geografis tertentu di Negara Kesatuan Republik Indonesia karena adanya ikatan pada asal usul leluhur, hubungan yang kuat dengan tanah, wilayah, sumber daya alam, memiliki pranata pemerintahan adat, dan tatanan hukum adat di wilayah adatnya sesuai dengan ketentuan peraturan perundang-undangan". Lebih lanjut lihat Pasal 23 huruf (f) terkait dengan usaha perikanan dan kelautan serta industri perikanan secara lestari. Selanjutnya UU Desa Tahun 2014 dalam Konsiderans menyebutkan Pasal 18B ayat (2) UUD 1945 merupakan salah satu dasar pertimbangan dibentuknya UU Desa Tahun 2014. Selanjutnya Bab XIII UU Desa Tahun 2014 mengatur Ketentuan Khusus Desa Adat pada Pasal 96 - Pasal 111. Lebih lanjut Penjelasan UU Desa Tahun 2014 mengatur ketentuan khusus bagi Provinsi Aceh, Provinsi Papua, dan Provinsi Papua Barat, Pemerintah Daerah Kabupaten/Kota dalam menetapkan kebijakan mengenai pengaturan desa disamping memperhatikan ketentuan UU Desa Tahun 2014 harus memerhatikan:

a. Undang-Undang Nomor 21 Tahun 2001 tentang Otonomi Khusus bagi Provinsi Papua sebagaimana telah diubah dengan Undang-Undang Nomor 35 Tahun 2008 tentang Penetapan Peraturan Pemerintah Pengganti Undang-Undang Nomor 1 Tahun 2008 tentang Perubahan atas Undang-Undang Nomor 21 Tahun 2001 tentang Otonomi Khusus bagi Provinsi Papua menjadi undang-undang; dan

b. Undang-Undang Nomor 11 Tahun 2006 tentang Pemerintahan Aceh.

c. Konsekuensi pembentukan UU Desa Tahun 2014 sebagaimana diatur Pasal 121 mencabut dan menyatakan Pasal 200-216 yang terdapat dalam Undang - Undang No. 32 tahun 2004 tentang Pemerintahan Daerah tidak berlaku lagi.

8 Nama Provinsi Nanggroe Aceh Darussalam (NAD) diatur dalam Undang-Undang Nomor 18 Tahun 2001 tentang Otonomi Khusus bagi Daerah Istimewa Aceh sebagai Provinsi Nanggroe Aceh Darussalam. Penyebutan NAD menggantikan nama sebelumnya yaitu Provinsi Daerah Istimewa Aceh. Sekarang, penyebutan Provinsi NAD diubah menjadi Provinsi Aceh berdasarkan Peraturan Gubernur Aceh No. 46 Tahun 2009 Tanggal 7 April 2009. Perubahan nama ini sesuai dengan amanat Pasal 251 UU Pemerintahan Aceh Tahun 2006.

9 Provinsi Aceh sebagai daerah khusus dan istimewa diatur melalui UU tentang Penyelenggaraan Keistimewaan Provinsi Daerah Istimewa Aceh Tahun 1999 tentang Penyelenggaraan Keistimewaan Provinsi Daerah istimewa Aceh, selanjutnya dibentuk UU Nomor 18 Tahun 2001 tentang Otonomi Khusus bagi Daerah Istimewa Aceh sebagaimana dicabut oleh UU Pemerintahan Aceh Tahun 2006.

10 UU Pemerintahan Aceh Tahun 2006 dalam Bab Ketentuan Umum Pasal 1 angka 2 Konsiderans huruf e. memberikan definisi: "Aceh adalah daerah provinsi yang merupakan kesatuan masyarakat hukum yang bersifat istimewa dan diberi kewenangan khusus untuk mengatur dan mengurus sendiri urusan pemerintahan dan kepentingan masyarakat setempat sesuai dengan peraturan perundang-undangan dalam sistem dan prinsip Negara Kesatuan Republik Indonesia berdasarkan UUD Tahun 1945, yang dipimpin oleh seorang Gubernur". 
Sri Walny Rahayu: Lembaga Penyelesaian Sengketa Adat Laut "Panglima Laôt" di Aceh sebagai Bentuk Pengembangan Alternatif Penyelesaian Sengketa dalam Sistem Hukum di Indonesia

Provinsi Aceh memiliki lembaga penyelesaian sengketa adat laut, yang dipimpin Panglima Laôt (Panglima Laut) sebagai lembaga APS yang telah ada sejak zaman kerajaan Sultan Iskandar Muda di abad ke-16. Lembaga Panglima Laôt merupakan identitas budaya (cultural identity) bagi Aceh. Kedudukannya kala itu sebagai pegawai pemerintahan, pemimpin wilayah laut dan pesisir di bidang ekonomi, memungut pajak dan cukai kelautan serta mengurusi persoalan keamanan di laut, yang diatur oleh Hukum Adat Laut (Hukôm Adat Laôt) bekerjasama dengan syahbandar dan uleebalang. ${ }^{11}$

Dewasa ini eksistensi lembaga Panglima Laôt di Aceh selain sebagai social leader persekutuan hukum masyarakat adat laut, juga merupakan lembaga APS adat laut Aceh. Dasar yuridis kedudukannya terdapat dalam UU Pemerintahan Aceh Tahun 2006 dan peraturan pelaksananya berupa Qanun-Qanun Aceh. Ruang lingkup penyelesaian sengketa adat laut adalah sengketa keperdataan di laut, penganiayaan ringan dan pencemaran lingkungan skala ringan yang diselesaikan melalui pelibatan aktif para pihak dengan putusan musyawarah mufakat tanpa melalui jalur litigasi.

Panglima Laôt terdiri dari Panglima Laôt Lhôk, Panglima Laôt kabupaten/kota dan Panglima Laôt Aceh. ${ }^{12}$ Kewenangannya menyelesaikan sengketa keperdataan kelautan dibatasi dari setiap pantai yang meliputi suatu kuala ${ }^{13}$ atau disebut laut (Laôt). Peraturan perundang-undangan umumnya memberikan definisi tentang Panglima Laôt sebagai pemimpin adat istiadat di bidang pesisir, kelautan, dan lembaga penyelesaian persengketaan di laut. Selain Panglima Laôt di Aceh, masih ada lembaga penyelesaian sengketa adat laut dan Hak Ulayat Laut (HUL) yang masih hidup dan bertahan lainnya yaitu Sasi di Maluku, Papua Utara, serta Awig-awig di Lombok Nusa Tengara Barat. Sasi dan Awig-awig lebih merupakan norma larangan dalam HUL masyarakat adat laut dan belum diatur dalam bentuk peraturan perundangundangan sebagaimana halnya lembaga Panglima Laôt di Aceh.

Berdasarkan latar belakang yang telah diuraikan sebelumnya, masalah yang memerlukan penelaahan mengenai bagaimana kedudukan lembaga penyelesaian sengketa adat laut Panglima Laôt dalam sistem hukum di Indonesia dan bagaimana

11 Uleebalang merupakan Bahasa Aceh yang berarti penguasa suatu wilayah pada struktur pemerintahan daerah pada Zaman Kesultanan Aceh. Sejak Kemerdekaan dan Aceh menjadi wilayah NKRI, Uleebalang dan kekuasaannya menjadi hilang. Jabatan Uleebalang dapat disamakan dengan jabatan bupati/walikota sekarang.

12 Kewenangan Panglima Laôt Lhôk berada pada satu kuala/teluk di tingkat kecamatan. Panglima Laôt Kabupaten berada di kabupaten/kota, sedangkan Panglima Laôt Aceh (PLA) berada di tingkat provinsi. PLA hanya merupakan lembaga adat bersifat koordinatif dan advokasi. Istilah PLA digunakan dalam UU Pemerintahan Aceh Tahun 2006, yang awalnya disebut Panglima Laôt Provinsi (PLP). Istilah PLA mulai digunakan setelah hasil musyawarah duek pakat Panglima Laôt Se-Aceh, 19-20 Maret 2001 di Sabang-Aceh.

13 Departemen Pendidikan Nasional, Kamus Besar Bahasa Indonesia Pusat Bahasa, Jakarta: Gramedia Pustaka Utama, 2008, hlm. 744. Kuala adalah teluk tempat pertemuan sungai dengan sungai atau sungai dengan laut: muara. Kuala atau teluk dalam Bahasa Daerah Aceh disebut dengan sebutan Lhôk. 
Sri Walny Rahayu: Lembaga Penyelesaian Sengketa Adat Laut "Panglima Laôt" di Aceh sebagai Bentuk Pengembangan Alternatif Penyelesaian Sengketa dalam Sistem Hukum di Indonesia

kekuatan hukum penyelesaian sengketa lembaga adat laut Panglima Laôt dalam pengembangan sistem hukum APS di Indonesia.

\section{B. Lembaga Penyelesaian Sengketa Adat Laut Panglima Laôt dalam Sistem Hukum di Indonesia}

Reformasi konstitusi UUD 1945 dalam Pasal 18B ayat (1) dan (2) jika dikaji mengatur dua entitas sosial-politik yang berbeda satu dengan yang lainnya. Pasal 18B ayat (1) mengakui kesatuan pemerintahan yang bersifat khusus/istimewa ditindaklanjuti melalui UU Pemda Tahun 2004. Pasal ini mengatur soal pengakuan dan penghormatan negara terhadap entitas satuan pemerintahan daerah yang memiliki hak khusus dan istimewa seperti Aceh, Papua, dan DKI Jakarta serta hak istimewa seperti Yogyakarta.

Pasal 18B ayat (2) mengatur mengenai pengakuan dan penghormatan terhadap kesatuan masyarakat hukum adat dan hak-hak tradisionalnya. Jika negara mengakui hak tradisional kesatuan masyarakat hukum adat, negara seharusnya memberikan ruang pengaturan lembaga penyelesaian sengketa adat yang berfungsi dan memiliki hak mengadili. ${ }^{14}$ Pengakuan negara tersebut merupakan pengesahan formal terhadap suatu entitas lembaga persekutuan hukum adat beserta hak-haknya. Kenyataannya, Pasal 18B ayat (2) belum diturunkan dalam bentuk UU sebagaimana amanah pasal tersebut. Hal ini menunjukkan bahwa negara mengakui hak kesatuan masyarakat hukum adat untuk mengurus rumah tangganya sendiri ketika berbentuk tertulis berupa peraturan perundang-undangan. Pengaturannya saat ini masih tersebar dan parsial. Adanya undang-undang sebagai pengaturan lebih lanjut Pasal 18B ayat (2) UUD 1945 merupakan hal mendesak karena menimbulkan sejumlah pertanyaan seperti batasan dan ruang lingkup pengertian hak-hak tradisional masyarakat hukum adat. Adapun permasalahan tersebut, selain diatur dalam Pasal 28 I ayat (3) UUD 1945 juga diatur dalam Pasal 6 ayat (1) dan ayat (2) UU HAM Tahun 1999.

Sistem peradilan di Indonesia memberi peluang untuk mengakomodasi lembaga penyelesaian sengketa adat sebagaimana diatur Pasal 24 ayat (3) UUD 1945. Dalam pasal ini, dinyatakan bahwa, "badan-badan lain yang fungsinya berkaitan dengan kekuasaan kehakiman diatur dalam undang-undang". ${ }^{15}$ Selanjutnya, hak tradisional yang sekaligus menjadi identitas budaya kesatuan masyarakat hukum adat sejauh ini dipahami sebagai pengakuan eksistensi masyarakat hukum adat memiliki hak

14 Gede Marhaendra Wija Atmaja, "Politik Hukum dalam Pengakuan Kesatuan Masyarakat Hukum Adat dengan Peraturan Daerah", Malang: Program Doktor Ilmu Hukum Universitas Brawijaya, 2012, hlm. 98.

15 Anonim, Sistem Peradilan Adat dan Lokal di Indonesia, Peluang \& Tantangan, Jakarta: Aliansi Masyarakat Adat Nusantara (AMAN)-Partnership for Governance Reform, 2003, hlm. 50. 
Sri Walny Rahayu: Lembaga Penyelesaian Sengketa Adat Laut "Panglima Laôt" di Aceh sebagai Bentuk Pengembangan Alternatif Penyelesaian Sengketa dalam Sistem Hukum di Indonesia

otonomi ketika diakui oleh negara. ${ }^{16}$

Sistem hukum Indonesia menganut asas legalitas namun penting untuk dicatat keberadaan Undang - Undang Nomor 48 Tahun 2009 tentang Kekuasaan Kehakiman (UU Kekuasaan Kehakiman Tahun 2009). Pasal 5 ayat (1) dan Pasal 50 ayat (1) UU Kekuasaan Kehakiman Tahun 2009 mengatur bahwa dalam memutus suatu perkara hakim wajib memerhatikan dan menggali nilai-nilai keadilan yang hidup, tumbuh, dan berkembang dalam masyarakat sesuai dengan hukum dan rasa keadilan. Hukum yang tidak tertulis dapat dijadikan sebagai salah satu sumber hukum.

Hukum adat bukanlah hukum formal meskipun nilai-nilai yang terkandung di dalamnya diturunkan melalui Batang Tubuh UUD 1945 Pasal 18B ayat (1) dan ayat (2) serta Pasal 281 ayat (3). Selain itu, sistem hukum di Indonesia didasarkan asas legalitas yang mengatur tidak adanya hukum selain hukum tertulis demi kepastian hukum. Hukum adat secara tegas tidak diatur dalam Undang-Undang Nomor 12 Tahun 2011 tentang Pembentukan Peraturan Perundang-undangan di Indonesia. Dengan demikian, sekalipun keberadaan hukum adat, persekutuan masyarakat hukum adat dan hak tradisonal, identitas budaya, serta kearifan lokalnya memiliki peran strategis dan penting dalam pembangunan hukum nasional di Indonesia. Pengakuan negara sebagai pengesahan formal terhadap kesatuan hukum masyarakat adat berikut hakhak tradisionalnya harus dalam bentuk undang-undang sebagaimana amanat Pasal 18 B ayat (2) UUD 1945.

\section{Panglima Laôt Sebagai Lembaga Penyelesaian Sengketa Adat Laut}

Lembaga penyelesaian sengketa adat laut di Aceh dalam melaksanakan kegiatan dan kehidupan sosialnya terikat norma Hukôm Adat Laôt berdasarkan ajaran Islam. Subjek persekutuan masyarakat adat laut adalah masyarakat nelayan (rechts subjecten) yang merupakan persekutuan masyarakat adat (rechts gemeenchappen), terikat dengan kepentingan bersama dalam bertingkah laku, bersikap, dan bertindak dalam pergaulan hidup masyarakatnya. Objek Hukôm Adat Laôt (rechts objecten) adalah lautan atau pesisir pantai, sarana penangkapan ikan baik tradisional maupun modern serta keputusan-keputusan adat tentang tata cara penangkapan ikan di laut (meupayang). Masyarakat nelayan dan pesisir di Aceh sebagai persekutuan hukum (rechts gemeenchappen) dan dalam pergaulan hukumnya, menjadi anggota kelompok yang bersikap dan bertindak sebagai suatu kesatuan. ${ }^{17}$

Uraian di atas menunjukkan bahwa pengakuan Panglima Laôt sebagai lembaga APS adat laut terdapat dalam peraturan perundang-undangan di Indonesia. Secara

16 Zen Zanibar, "Masyarakat Hukum Adat", dalam Lampiran Laporan Diskusi Terbatas Kedudukan Hukum Kesatuan Masyarakat Hukum Adat dan Keterkaitannya dengan Pemekaran Wilayah, Jakarta: Mahkamah Konstitusi Republik Indonesia, 3 Juni 2008, hlm. 7.

17 Hasil wawancara dengan Syamsuddin Daud, Wakil Ketua Majelis Adat Aceh (MAA) dan lembaga Panglima Laôt Aceh, 10-13 Oktober 2012. 
Sri Walny Rahayu: Lembaga Penyelesaian Sengketa Adat Laut "Panglima Laôt" di Aceh sebagai Bentuk Pengembangan Alternatif Penyelesaian Sengketa dalam Sistem Hukum di Indonesia

implisit, Pasal 18B ayat (1) dan (2) serta Pasal 28 I ayat (3) UUD 1945, jo. UU Kelautan Tahun 2009, UU No. 1 Tahun 2014, UU Desa Tahun 2014. Pengaturan secara eksplisit diatur dalam Pasal 98 ayat (1), (2), (3) huruf i sampai ayat (4) jo. Pasal 162 huruf e UU Pemerintahan Aceh Tahun 2006. Diatur dalam Pasal 11 Qanun No. 16 Tahun 2002 tentang Pengelolaan Sumber Daya Kelautan dan Perikanan. ${ }^{18}$ Qanun No. 9 Tahun 2008 tentang Pembinaan Kehidupan Adat Istiadat, Qanun No. 10 Tahun 2008 tentang Lembaga Adat, Peraturan Gubernur Aceh No. 60 Tahun 2013 tentang Pelaksanaan Penyelesaian Sengketa/Perselisihan Adat dan Istiadat, Surat Keputusan Gubernur Aceh Nomor 523/315/2000 tentang Pengukuhan Panglima Laôt, Keputusan Gubernur Provinsi Aceh Nomor: 523.11/012/2005 tanggal 8 Maret 2005 tentang Tugas dan Wewenang Panglima Laôt. Panglima Laôt juga merupakan bagian dari Forum Masyarakat Perikanan Dunia atau World Fisher Forum People (WFFP) tahun 2007.

\section{Panglima Laôt dalam Hukôm Adat Laôt di Aceh}

Dasar pengakuan terhadap Panglima Laôt berdasarkan Pasal 18B ayat (2) dan Pasal 28 I ayat (3) UUD 1945 memiliki syarat realitas dan idealitas. Syarat realitas yaitu negara akan memberikan jaminan dan penghormatan kepada hukum adat beserta hak-hak tradisional masyarakat adat laut dan pesisir di Aceh jika masih hidup dan sesuai dengan perkembangan masyarakat. Syarat idealitas yaitu adanya kesesuaian syarat realitas tersebut dengan prinsip Negara Kesatuan Republik Indonesia dan keberlakuannya diatur oleh undang-undang.

Fakta menunjukkan bahwa kedudukan dan kewenangan Panglima Laôt dan Hukôm Adat Laôt diakui dan terdapat dalam hukum positif di Indonesia. Kedudukan hukum dengan adat di Aceh diilustrasikan sebagai, "Adat meukoh reubong, Hukôm meukoh purieh, Adat hanjeut berangkaho takhong, Hukôm hanjeut berangkaho takieh". Makna ungkapan tersebut adalah adat sifatnya dapat berubah sesuai dengan perkembangan zaman, ibarat tunas bambu muda (reubong), sekalipun tidak mudah juga untuk dilanggar. Hukum sifatnya ibarat purieh (bambu tua yang sudah sangat kering), sehingga tidak mudah untuk dipotong, tidak mudah berubah dan tidak dapat diberikan pemahaman secara sembarangan. ${ }^{19}$

18 Peraturan daerah di Aceh disebut Qanun berdasarkan Undang-Undang No. 18 Tahun 2001 tentang Otonomi Khusus bagi Daerah Istimewa Aceh sebagai Provinsi NAD dan UU Pemerintahan Aceh Tahun 2006. Qanun dalam UU Pemerintahan Aceh Tahun 2006 terdiri dari Qanun Aceh dan Qanun Kabupaten/Kota. Qanun Aceh adalah peraturan perundang-undangan sejenis peraturan daerah Provinsi yang mengatur penyelenggaraan pemerintahan dan kehidupan masyarakat Aceh (Pasal 1 angka 21 UU Pemerintahan Aceh Tahun 2006). Qanun Kabupatan/Kota adalah peraturan perundang-undangan sejenis peraturan daerah kabupaten/kota yang mengatur penyelenggaraan pemerintahan dan kehidupan masyarakat Kabupaten kota di Aceh (Pasal 1 angka 22 UU Pemerintahan Aceh Tahun 2006).

19 Lihat Darwis dalam Syahrizal, "Hubungan antara Hukum Adat dan Hukum Islam dalam Masalah Kewarisan di Aceh”, Bandung: Program Pascasarjana Universitas Padjajaran , 2001, hlm. 168. 
Sri Walny Rahayu: Lembaga Penyelesaian Sengketa Adat Laut "Panglima Laôt" di Aceh sebagai Bentuk Pengembangan Alternatif Penyelesaian Sengketa dalam Sistem Hukum di Indonesia

Hukôm Adat Laôt bersifat keperdataan yaitu usaha untuk memenuhi kebutuhan ekonomi harus seimbang dengan kelestarian habitat dan keberlanjutan ekosistem. Selain itu Hukôm Adat Laôt mengatur tata cara operasional melaut, adat sosialekonomi masyarakat nelayan, penangkapan ikan di laut, bagi hasil, sewa-menyewa, pengupahan, dan lain-lain. Pengaturan tempat penambatan perahu dan pukat di pantai, tempat penjemuran alat penangkapan ikan dan memperbaiki kerusakan baik alat penangkapan ikan maupun perahunya, waktu larangan melaut, penemuan harta di laut, penyelesaian sengketa di laut, perusakan lingkungan, pencarian ikan di laut, kecelakaan di laut, kenduri laut serta semua kegiatan yang berhubungan dengan mencari nafkah di laut.

Pemerintah Aceh melakukan langkah progresif dengan menempatkan lembaga APS adat laut dan Hukôm Adat Laôt ke dalam produk peraturan perundang-undangan Indonesia. Hukum Adat Laut di Aceh dapat berfungsi mengisi kekosongan hukum positif jika belum ada pengaturannya secara nasional mengenai persekutuan adat laut dan lembaga penyelesaian sengketa adat laut. Bentuk Hukum Adat Laut yang semula bersifat lokal kedaerahan yang pada dasarnya tidak tertulis, setelah beberapa kali duek pakat (pertemuan) berhasil diinventarisasi dan didokumentasikan dalam bentuk undang-undang serta Qanun-qanun Aceh dan Qanun kabupaten/kota.

\section{Peraturan Perundang-undangan tentang Panglima Laôt dan Hukôm Adat Laôt} Pada tahun 1973, ditemukan dokumen dari Dinas Perikanan Daerah Provinsi Daerah Istimewa Aceh (sekarang menjadi Dinas Perikanan dan Kelautan Provinsi Aceh) berjudul "Monografi Perikanan Daerah, Provinsi Daerah Istimewa Aceh" yang mendefinisikan kedudukan Panglima Laôt, meskipun kedudukannya baru sebatas sebagai pelaksana teknis perikanan laut, tidak dalam arti dan kapasitasnya sebagai penguasa wilayah pesisir dan laut sebagaimana awal pembentukannya. ${ }^{20}$ Panglima Laôt meskipun dikonsepsikan sebagai ketua lembaga adat bagi kehidupan nelayan di pantai, namun dalam praktiknya di tingkat Lhôk, Panglima Laôt melaksanakan proses penyelesaian sengketa adat dengan menyelesaikan sengketa kelautan yang timbul di antara nelayan. Hal ini berarti lembaga Panglima Laôt aktif melaksanakan proses peradilan berdasarkan Hukôm Adat Laôt.

Pada tahun 1977, aturan tertulis lembaga Panglima Laôt pertama kali dibentuk dalam tatanan pemerintahan daerah sebagai organisasi pemerintahan berdasarkan Surat Keputusan Bupati Aceh Besar Nomor 1 Tahun 1977 tentang Struktur Organisasi Pemerintahan di Daerah Pedesaan Aceh Besar. Meskipun aturan tersebut tidak secara rinci mengatur mengenai peran, kedudukan dan fungsi Panglima Laôt. ${ }^{21}$ Aturan tersebut dapat dikatakan telah menginspirasi lahirnya Peraturan Daerah

20 Dinas Perikanan Daerah Provinsi Daerah Istimewa Aceh, Monografi Perikanan Daerah, Banda Aceh: Penerbit Dinas Perikanan Daerah Propinsi Daerah istimewa Aceh, 1977, hlm. 2.

$21 \mathrm{lbid}$. 
Sri Walny Rahayu: Lembaga Penyelesaian Sengketa Adat Laut "Panglima Laôt" di Aceh sebagai Bentuk Pengembangan Alternatif Penyelesaian Sengketa dalam Sistem Hukum di Indonesia

Provinsi Daerah Istimewa Aceh Nomor 2 Tahun 1990 tentang Pembinaan dan Pengembangan Adat Istiadat (Perda No. 2 Tahun 1990).

Pada tahun 1990, keberadaan Panglima Laôt mulai diatur kembali dalam sistem hukum negara yang sempat hilang setelah Indonesia merdeka melalui Perda No. 2 Tahun 1990. Kedudukan lembaga Panglima Laôt berada di luar struktur organisasi pemerintahan dan hanya merupakan orang-orang yang memimpin adat istiadat serta kebiasaan yang berlaku di bidang penangkapan ikan di laut. Selain itu, lembaga ini bertanggung jawab kepada kepala daerah setempat (gubernur, bupati, camat, kepala desa/geuchik). Perda No. 2 Tahun 1990 juga menyatakan Panglima Laôt merupakan unsur penghubung antara Pemerintah dan nelayan di tepi pantai guna menyukseskan program pembangunan perikanan. ${ }^{22}$ Pada masa tersebut, Panglima Laôt diposisikan sebagai lembaga adat semata.

Tujuan pembangunan nasional Indonesia dalam Rencana Pembangunan Jangka Panjang Nasional Tahun 2005-2025 untuk mewujudkan integrasi dan mengoptimalkan partisipasi masyarakat. Provinsi Aceh termasuk dalam pengembangan wilayah kelautan Sumatera dan Malaka periode 2010-2014. Program kebijakan makro kelautan di Indonesia mengatur kearifan lokal sangat diperlukan untuk menjamin sumber daya alam dan pelestarian lingkungan hidup. Pendekatan pengelolaan perikanan ditekankan pada perpaduan antara ekonomi, sosial, dan lingkungan.

Kelembagaan dalam konteks desentralisasi dan otonomi pengelolaan sumber daya kelautan dan perikanan harus dilihat sebagai bentuk pengelolaan bersama pada level global, nasional, regional, dan lokal. Khusus di level lokal, pengelolaan bersama harus mempertimbangkan hak masyarakat lokal, hukum adat, institusi, dan kearifan lokal dalam masyarakat sebagai wujud partisipasi dan kemandirian masyarakat dalam pengelolaan sumber daya kelautan dan perikanan. Paradigma pembangunan seperti inilah yang sangat dibutuhkan.

\section{Kekuatan Hukum Penyelesaian Sengketa Bisnis Kelautan Panglima Laôt sebagai Pengembangan Sistem Hukum APS}

Penegakan hukum dan penyelesaian sengketa jika dikaitkan dengan pendapat Mochtar Kusumaatmadja yang menyatakan bahwa masyarakat yang sedang membangun selalu dicirikan oleh perubahan dan hukum berfungsi untuk menjamin perubahan tersebut terjadi secara teratur. ${ }^{23}$ Hukum tidak hanya berupa kaidah, norma atau asas, tetapi juga merupakan suatu gejala sosial yang terdapat dalam

22 Dinas Perikanan Provinsi Daerah Istimewa Aceh, Keputusan Pertemuan Panglima Laôt / Musyawarah Panglima Laôt se-Provinsi Daerah Istimewa Aceh, Kabupaten Aceh Timur, tanggal 23-25 Januari 1992.

23 Mochtar Kusumaatmadja, Fungsi dan Perkembangan Hukum dalam Pembangunan Nasional, Bandung: Binacipta, 1976, hlm. 11. 
Sri Walny Rahayu: Lembaga Penyelesaian Sengketa Adat Laut "Panglima Laôt" di Aceh sebagai Bentuk Pengembangan Alternatif Penyelesaian Sengketa dalam Sistem Hukum di Indonesia

masyarakat. Hukum yang baik adalah hukum yang sesuai dengan hukum yang hidup (the living law), yang merupakan pencerminan dari nilai yang berlaku dalam masyarakat.

Lembaga Panglima Laôt sebagai lembaga APS adat kelautan bersifat otonom. Penyelesaiannya menggunakan cara berdasarkan hukum yang hidup (the living law) yang merupakan pencerminan nilai yang berlaku dalam masyarakat Aceh. Di Indonesia, selain Lembaga Panglima Laôt, dikenal pula Sasi di Maluku dan Awig-awig di Lombok. Sasi dan Awig-awig memiliki spesialisasi kelembagaan penyelesaian sengketa adat laut dalam bentuk yang sangat sederhana. Sasi dan Awig-awig sebagai persekutuan hukum adat laut hanya mengenal standar tingkah laku dan belum terdiferensiasi sebagaimana halnya lembaga Panglima Laôt. Penulis berpendapat bahwa persekutuan hukum adat laut Sasi dan Awig-awig belum dapat dikatakan sebagai model lembaga APS adat laut sebagaimana halnya lembaga Panglima Laôt. Hal ini dikarenakan persekutuan hukum adat laut tersebut belum memiliki peraturan terperinci dalam bentuk produk peraturan perundang-undangan. Berkaitan dengan struktur persekutuan hukum masyarakatnya, Penulis merujuk pada pendapat Esmi Warassih yang menyatakan komunitas kecil berdasarkan kekerabatan sekalipun memiliki kontrol sosial namun belum optimal dalam menjalankan fungsi kontrol sosialnya secara efektif. ${ }^{24}$

Panglima Laôt mempraktikkan pola pendekatan penyelesaian sengketa win-win solution yang berpedoman pada nilai kearifan lokal yang masih hidup dan dipertahankan masyarakat hukum adat di Aceh seperti diilustrasikan dalam hadih maja, "meunyoe ka tameupakat lampoh jeurat ta peugala" (kalau sudah ada kata mufakat kuburan pun dapat digadaikan). Pepatah ini mengandung makna bahwa kuburan yang memiliki nilai spiritual dan magis bagi masyarakat Aceh rela digadaikan, demi memperoleh kesepakatan.

Panglima Laôt menyelesaikan sengketa kelautan menggunakan tolok ukur asas keselarasan, kerukunan dan kepatutan. Kondisi ini menunjukkan adanya sebuah sistem hukum yang menjamin setara seluruh kebutuhan tertib sosial dalam realitas sosial yang beragam. Fakta tersebut menunjukkan setiap persekutuan hukum adat memiliki kapasitas untuk membangun otonominya sendiri termasuk menyelesaikan persoalan dan urusannya sendiri. Penyelesaiannya dalam waktu singkat, murah, tidak formal, tidak memunculkan bibit permusuhan, tidak ada pihak kalah maupun menang dalam putusannya serta sangat mendukung aktivitas perekonomian masyarakat.

24 Esmi Warassih dalam Eman Suparman, Pilihan Forum Arbitrase dalam Sengketa Komersial untuk Penegakan Keadilan, Jakarta: Tatanusa, 2004. hlm. 35-36. Bandingkan dengan Esmi Warassih, Pemberdayaan Masyarakat dalam Mewujudkan Tujuan Hukum (Proses Penegakan Hukum dan Persoalan Keadilan), Pidato Pengukuhan, Fakultas Hukum Universitas Diponegoro, Semarang, 14 April 2001. 
Sri Walny Rahayu: Lembaga Penyelesaian Sengketa Adat Laut "Panglima Laôt" di Aceh sebagai Bentuk Pengembangan Alternatif Penyelesaian Sengketa dalam Sistem Hukum di Indonesia

Penulis memahami bahwa sistem hukum inilah yang merupakan ciri khas masyarakat Indonesia yaitu dinamis terhadap perubahan. Pembangunan hukum tanpa meninggalkan performa aslinya, melainkan bentuk hukum yang tumbuh dalam masyarakat diangkat menjadi hukum positif di Indonesia. Hukum barat belum tentu cocok sepenuhnya karena sesuatu hal yang implan dan instan justru dapat menjadi bumerang bagi diri sendiri.

Dalam praktiknya, para pihak lebih memilih Panglima Laôt untuk meyelesaikan sengketa bisnis kelautan dan keperdataan lainnya dibanding menyelesaikannya melalui peradilan negara. Lembaga penyelesaian sengketa adat sebenarnya dapat berperan mengurangi menumpuknya kasus perdata di pengadilan negara, termasuk mengisi kekosongan hukum. Tantangannya dalam masyarakat di Indonesia adalah mendokumentasikan pola-pola penyelesaian sengketa dalam persekutuan masyarakat hukum adat antara lain persekutuan masyarakat adat laut dan secara laboratoris mengembangkan corak-corak APS yang merupakan produk bangsa Indonesia asli.

Panglima Laôt sebagai lembaga APS adat laut meskipun bukan merupakan bagian Pemerintahan di Aceh tetapi menjadi mitra pemerintah. Lembaga penyelesaian sengketa adat laut tersebut telah memiliki rules of recognition, rules of change, dan rules of adjudication. Masing-masing kaidah (rules) tersebut memegang otoritas untuk menentukan apa yang merupakan hukum, bagaimana mengubahnya dan bagaimana menyelesaikan suatu sengketa. ${ }^{25}$ Fungsi, tugas, dan kewenangannya selain diatur oleh Hukôm Adat Laôt juga diatur dalam undang-undang dan peraturan pelaksana di bawahnya. Aturan adat laut di Aceh merupakan proses bottom up bukan aturan top down atau produk hukum impor yang dimasukkan ke dalam Hukôm Adat Laôt.

Ruang lingkup penyelesaian sengketa/perselisihan, yang diselesaikan Panglima Laôt diatur rinci dalam Peraturan Gubernur (Pergub) Aceh Nomor 60 Tahun 2013 tentang Pelaksanaan Penyelesaian Sengketa/Perselisihan Adat Istiadat meliputi: persengketaan di laut (Pasal 3 huruf f); penganiayaan ringan (Pasal 3 huruf g); dan pencemaran lingkungan skala ringan (Pasal 3 huruf j). Adapun penjabaran persengketaan antar nelayan di laut dalam Pasal 3 huruf $f$ adalah:

a. Pertengkaran, perkelahian yang tidak menimbulkan cedera fisik antara sesama nelayan;

b. Persengketaan bagi hasil tangkapan; dan

c. Perselisihan hak atas kawanan ikan antar nelayan.

Pada Pasal 9 ayat (2) dijelaskan pencemaran lingkungan skala ringan sebagaimana dimaksudkan Pasal 3 huruf j meliputi :

25 H.L.A. Hart, The Concept of Law, terjemahan M. Khozim, Bandung: Nusa Media, 2009, hlm. 89-96. 
Sri Walny Rahayu: Lembaga Penyelesaian Sengketa Adat Laut "Panglima Laôt" di Aceh sebagai Bentuk Pengembangan Alternatif Penyelesaian Sengketa dalam Sistem Hukum di Indonesia

a. Penangkapan ikan di kawasan muara/kuala dengan alat tertentu sesuai dengan adat setempat;

b. Wilayah tangkap dan/atau alat tangkap;

c. Melaut di hari pantangan melaut;

d. Penangkapan jenis ikan tertentu yang dilarang oleh hukum adat laut;

e. Perusakan terumbu karang dalam wilayah pengelolaan kawasan hukum adat; dan

f. Perusakan hutan pantai.

Penganiayaan ringan yang dimaksud Pasal 3 huruf g dijabarkan dalam Pasal 10 yakni penganiayaan yang tidak menimbulkan pendarahan berat dan/atau tidak menimbulkan cacat fisik dan/atau psikis (Pasal 10). Penyelesaian yang menjadi kewenangan Panglima Laôt lainnya yang dimaksud Pasal 3 huruf I meliputi tindak pidana pelecehan, fitnah, hasut, dan pencemaran nama baik. Pencemaran nama baik diuraikan dalam Pasal 12 ayat (1) sebagai segala perbuatan yang menimbulkan rasa tidak senang atau tidak nyaman atau yang merendahkan martabat kemanusiaan. Pelecehan, fitnah, hasut dan pencemaran nama baik sebagaimana dimaksud pada Pasal 12 ayat (1) diatas, diselesaikan oleh lembaga adat atas permintaan pihak yang dirugikan dan/atau atas persetujuan para pihak (Pasal 12 ayat (2)).

Tindakan pencemaran lingkungan yang dimaksud Pasal 3 huruf j dijabarkan dalam Pasal 13 yakni meracun/menuba dan menyetrum ikan yang dilakukan di batang air (sungai dan alur), lubuk, muara sungai, danau dan suak (kawasan payau). Adapun ancam-mengancam yang dimaksud Pasal 3 huruf $k$ meliputi segala bentuk ancaman melalui perbuatan, perkataan, simbol-simbol tertentu tanpa kekerasan fisik yang mengancam keselamatan jiwa dan/atau harta benda milik seseorang. Panglima Laôt dapat menerapkan sanksi berupa nasihat, teguran, pernyataan maaf, sayam, diyat, denda adat, ganti kerugian, pengucilan, pengusiran, dan pencabutan gelar adat (Pasal 20).

Pada Pergub No. 60 Tahun 2013 diatur bahwa Panglima Laôt tidak hanya menyelesaikan sengketa keperdataan kelautan semata tetapi juga memiliki kewenangan untuk menyelesaikan bentuk tindak pidana ringan (tipiring) yang muncul akibat persengketaan di laut yang bermula dari hubungan keperdataan. Hal ini sesuai dengan sifat hukum adat yang tidak mengenal pembagian antara hukum perdata dan pidana. Tindak pidana yang diselesaikan melalui forum APS Panglima Laôt merupakan tipiring sebagaimana diatur Pasal 10. Adapun tindak pidana pencemaran lingkungan diatur dalam Pasal 13.

Selain sanksi yang diatur dalam Pergub No. 60 Tahun 2013, terdapat juga sanksi Hukôm Adat Laôt. $^{26}$ Nelayan yang melanggar ketentuan hari pantang ke laut 
Sri Walny Rahayu: Lembaga Penyelesaian Sengketa Adat Laut "Panglima Laôt" di Aceh sebagai Bentuk Pengembangan Alternatif Penyelesaian Sengketa dalam Sistem Hukum di Indonesia

dikenakan tindakan hukum. Adapun sanksi hukumnya berupa:

1) Penyitaan seluruh hasil tangkapan;

2) Pelarangan melaut minimum tiga hari dan maksimum tujuh hari jika terjadi pelanggaran-pelanggaran terhadap tindakan hukum yang telah ditetapkan;

3) Jika terjadi pelanggaran-pelanggaran terhadap tindakan hukum yang telah ditetapkan, maka Lembaga Persidangan Hukôm Adat Laôt (LPHAL) melakukan tindakan administratif melalui pejabat yang berwenang setelah melakukan musyawarah dengan staf Lembaga Hukôm Adat Laôt.

Hukôm Adat Laôt sangat menekankan pada pentingnya keseimbangan antara usaha untuk memenuhi kebutuhan ekonomi dengan kelestarian habitat serta keberlanjutan ekosistem. Konsep tersebut berhubungan dengan adanya keseimbangan vertikal dengan Sang Maha Pencipta dan horizontal sesama umat manusia. Larangan turun ke laut pada hari-hari tertentu seperti hari Jumat, hari raya dan hari-hari besar Islam termasuk peringatan tsunami setiap tanggal 26 Desember setiap tahunnya, bukan karena prosesi adat semata. Tujuan dari larangan tersebut antara lain untuk memberikan kesempatan bagi biota laut agar dapat berkembang biak dan untuk nelayan agar dapat memperbaiki kapalnya. Semua bekas perbaikan kapal tidak boleh dibuang sembarangan, termasuk melarang penggunaan alat-alat penangkapan yang tidak ramah lingkungan, bersosialisasi dengan sesama, terus meningkatkan ketakwaan kepada Tuhan YME, menjaga keseimbangan antara alam dengan mahluknya dan selalu mengenang peristiwa gempa bumi dan tsunami 26 Desember 2004 sebagai pelajaran berharga untuk selalu menjaga kelestarian alamnya.

Mekanisme APS melalui LPHAL memiliki karakteristik unik. ${ }^{27}$ Peneliti menginventarisasinya sebagai berikut:

1) Para pihak yang tidak puas terhadap Putusan Panglima Laôt Lhôk dapat melimpahkan penyelesaiannya ke Panglima Laôt Kabupaten/Kota;

2) Putusan Panglima Laôt Kabupaten/Kota bersifat final dan mengikat, berkekuatan hukum tetap, dapat dipaksakan putusannya bagi para pihak. Para

kerugian dan dampak yang ditimbulkan serta kondisi sosial ekonomi para pihak yang bersengketa/berselisih. Sanksi diberlakukan secara bertahap sesuai kesepakatan antara para pihak/pelaku dengan Panglima Laôt.

27 Mekanisme penyelesaian sengketa terdapat dalam Pergub No. 60 Tahun 2013 Bab IV Pasal 16 tentang Mekanime Peradilan Adat, ayat (1), ayat (4), ayat (5), ayat (6), ayat (7) jo. Pasal 19 ayat (1) yang dinyatakan bahwa setiap sengketa/perselisihan yang diajukan dicatat dalam Buku Registrasi Perkara. Pada Pasal 19 ayat (2), setelah menerima laporan wajib memberikan Surat Tanda Laporan dan tembusannya disampaikan ke kepolisian sektor. Pada Pasal 19 ayat (3), putusan tersebut dituangkan dalam bentuk Berita Acara Peradilan Adat dan dibukukan dalam Buku Induk Penyelesaian Perkara. Pasal 19 ayat (5), semua proses penyelesaian sengketa/perselisihan harus didokumentasikan oleh Sekretaris Panglima Laôt. Pada Pasal 19 ayat (6), setiap putusan yang bersifat tindak pidana ringan (persengketaan di laut, penganiayaan ringan, pelecehan, fitnah, hasut, pencemaran nama baik, pencemaran lingkungan skala ringan, ancam-mengancam) wajib dilaporkan ke kepolisian sektor, camat dan MAA Kecamatan selambat-lambatnya tiga hari dari tanggal penyelesaian. 
Sri Walny Rahayu: Lembaga Penyelesaian Sengketa Adat Laut "Panglima Laôt" di Aceh sebagai Bentuk Pengembangan Alternatif Penyelesaian Sengketa dalam Sistem Hukum di Indonesia

pihak tidak dapat mengajukan masalahnya lagi ke PLA. PLA hanya merupakan lembaga yang bersifat koordinatif bukan merupakan lembaga penyelesaian sengketa masyarakat adat laut;

3) Pihak yang mengajukan masalah ke Lembaga Persidangan Hukum Adat baik tingkat Lhôk/kecamatan maupun kabupaten/kota, tidak boleh mendaftarkan perkaranya melewati hari Kamis serta membayar uang meja sebesar lima belas ribu rupiah. Persidangan selalu dilaksanakan pada hari Jumat. Waktunya sebelum shalat atau sesudah shalat Jumat. Hal ini dikarenakan hari Jumat merupakan hari pantangan nelayan ke laut. Larangan ini diambil berdasarkan ajaran agama Islam yang mewajibkan laki-laki cukup umur (akil baligh) untuk shalat Jumat. Tujuan lainnya dari larangan tersebut adalah untuk melestarikan lingkungan laut dan menjadikannya sebagai hari bersosialisasi antarsesama termasuk menyelesaikan masalah-masalah yang terjadi di antara mereka. ${ }^{28}$ Para pihak yang bersengketa wajib hadir berikut saksi-saksi jika para pihak tidak hadir, maka Panglima Laôt memutuskan untuk menerima gugatan, menolak gugatan atau menunda sidang pada hari Jumat berikutnya. Dalam praktik, tidak ditemukan pihak yang bersengketa tidak hadir. Panggilan untuk menghadiri sidang ditentukan tiga kali berturut-turut. Jika para pihak tidak hadir setelah tiga kali dipanggil, maka Panglima Laôt menolak gugatan dengan sanksi pihak yang bersengketa harus membayar $10 \%$ dari harga ikan yang disengketakan dan menjadi hak Lembaga Hukum Adat Laôt. ${ }^{29}$

4) Panglima Laôt menggunakan semua bentuk APS seperti konsiliasi dan mediasi, bahkan penilaian ahli meskipun adanya kecenderungan sistem yang digunakan hampir mirip dengan pengaturan arbitrase dalam UU Arbitrase dan APS. Kesamaan lainnya dengan arbitrase, Panglima Laôt dapat dikatakan sebagai pengadilan wasit bersifat judikasi adversarial. Perbedaan yang signifikan adalah dalam penyelesaian sengketa Panglima Laôt tidak ada perjanjian tertulis/klausul diantara para pihak sebelumnya seperti syarat arbitrase dalam UU Arbitrase dan APS. Hal lainnya para pihak diberikan peluang banding ke Panglima Laôt Kabupaten. Hal ini berbeda dengan arbitrase yang putusannya bersifat final dan mengikat (tidak mengenal banding);

5) Tempat pelaksanaan sidang fleksibel (Balai Nelayan, Kantor Lembaga Hukum Adat Laôt, Kantor Perikanan atau Mesjid/Surau (Meunasah);

6) Hukum acara yang digunakan dalam memeriksa perkara LPHAL sangat sederhana dan tidak mengacu ke hukum acara HIR/RBG ${ }^{30}$ Pengambilan keputusan meminta

Hasil wawancara dengan Kadis Dinas Kelautan dan Perikanan (DKP) Aceh Utara, masyarakat nelayan dan empat Panglima Laôt, yaitu Panglima Laôt Kota Banda Aceh, Aceh Jaya, Bireuen, Lhôkseumawe;

29 Hasil Wawancara dengan Syamsuddin Daud, Wakil Ketua Majelis Adat Aceh (MAA).

30 Tata cara persidangan diatur dalam Peraturan Gubernur Nomor 60 Tahun 2013.
} 
Sri Walny Rahayu: Lembaga Penyelesaian Sengketa Adat Laut "Panglima Laôt" di Aceh sebagai Bentuk Pengembangan Alternatif Penyelesaian Sengketa dalam Sistem Hukum di Indonesia

pertimbangan/nasihat dari Dinas Kelautan dan Perikanan, camat/bupati/ walikota (muspika/muspida) serta tokoh adat laut. Konsep ini hampir mirip dengan sistem juri di Amerika Serikat dalam bentuk sederhana sesuai dengan kondisi masyarakat adat;

7) Kewenangannya meliputi hukum privat dan publik karena menjangkau tipiring yang diatur Pergub No. 60 Tahun 2013. Hal tersebut dikarenakan hukum adat tidak mengenal pembagian lingkup privat dengan publik. Jika ditelusuri, Pasal 24 ayat (3) UUD 1945 membuka peluang adanya lembaga penyelesaian sengketa adat di Indonesia yang memiliki fungsi mengadili. ${ }^{31}$ Peluang lainnya terdapat dalam Pasal 5 ayat (1) dan Pasal 50 ayat (1) UU Kekuasaan Kehakiman Tahun 2009.

8) Lembaga penyelesaian sengketa adat laut meskipun tidak diatur dalam konstitusi negara namun karena kekhususan Provinsi Aceh di bidang adat istiadat, eksistensi dan kewenangan, kedudukan Panglima Laôt sebagai forum APS kelautan menjadi kuat dan mendapat pengakuan hukum. Berpijak dari fakta ini, Penulis berpendapat bahwa kewenangan untuk melaksanakan fungsi mengadili dan memutuskan lembaga Panglima Laôt memiliki karakteristik yang unik dan bernuansakan lex specialist derogat lex generali.

Hukum adat laut terus berkembang bersama dengan tumbuhnya kebudayaan masyarakat adat laut dan pesisir di Aceh. Panglima Laôt dan hukum adat Laôt berperan sebagai subjek pembaruan masyarakat. Hukum adat laut tetap dipatuhi tanpa ada paksaan dan dijalankan sesuai dengan nilai budaya, norma-norma kearifan dan pengetahuan lokal yang diadopsi oleh peraturan perundang-undangan dalam konteks khusus Aceh dan nasional. Panglima Laôt dan Hukôm Adat Laôt di Aceh merupakan model pembangunan masyarakat adat yang modern, tanpa meninggalkan identitas aslinya yang tradisional bahkan memperkuatnya melalui produk hukum tertulis dalam legalitasnya sebagai penyelesaian sengketa adat laut yang diakui secara nasional.

Penulis berpandangan bahwa hukum APS Indonesia pengaturannya masih bersifat umum, tidak jelas, tidak terperinci dan tidak tegas. Pengaturan APS dalam UU Arbitrase dan APS sekedar melengkapi saja daripada tidak ada pengaturan sama sekali. Hal ini berisiko mengenyampingkan ciri-ciri khusus yang dimiliki APS yang tidak dapat disamaratakan begitu saja, terutama berkaitan dengan bentuk-bentuk APS dan mekanisme penyelesaiannya. Kehidupan modern, kompleks, dan spesialistis membutuhkan aturan yang komprehensif, proporsional bukan menyamakan bahkan menyederhanakan antara arbitrase dengan APS yang merupakan dua isu dan bentuk

31 Anonim, Sistem Peradilan Adat dan Lokal di Indonesia, Peluang \& Tantangan, Jakarta: Aliansi Masyarakat Adat Nusantara (AMAN)-Partnership for Governance Reform, 2003, hlm. 50. 
Sri Walny Rahayu: Lembaga Penyelesaian Sengketa Adat Laut "Panglima Laôt" di Aceh sebagai Bentuk Pengembangan Alternatif Penyelesaian Sengketa dalam Sistem Hukum di Indonesia

penyelesaian yang berbeda. Arbitrase memiliki sifat ajudikasi adversarial, sedangkan sistem APS bersifat ajudikasi non-adversarial. Konsekuensi dalam praktiknya, masalah-masalah yang seharusnya dapat diselesaikan melalui mekanisme APS justru kembali ke jalur litigasi.

Kekuatan hasil putusan berdasarkan penyelesaian APS dalam UU Arbitrase dan APS Tahun 1999 berkaitan dengan Pasal 1338 KUH Perdata yaitu: "perjanjian yang dibuat secara sah berlaku sebagai undang-undang bagi yang membuatnya". Perlu dicatat, Pasal 1338 KUH Perdata menganut prinsip kebebasan berkontrak (freedom of contract). Para pihak diberikan kebebasan untuk berkontrak serta mengatur poinpoin perikatan yang akan disepakati dan dilaksanakan bersama dalam kontrak.

Kemudian, adanya kebebasan para pihak untuk memilih ataupun menyepakati langkah proses penyelesaian sengketa diluar pengadilan (nonlitigasi). Pemilihan penyelesaian sengketa melalui mekanisme APS tidak dapat dipaksakan oleh satu pihak kepada pihak lainnya. Namun ketika hal tersebut berkaitan dengan kesepakatan untuk memilih mekanisme APS, maka para pihak terikat pada perjanjian yang dibuatnya dengan memperhatikan Pasal 1320 KUH Perdata tentang syarat sahnya suatu perjanjian. Dalam hal ini, sebenarnya para pihak dapat merujuk asasasas APS untuk mematuhi kesepakatan yang mereka buat. Dalam praktiknya, asas iktikad baik dan pacta sunt servanda diabaikan oleh para pihak.

\section{Penutup}

Kedudukan Panglima Laôt sebagai lembaga APS bisnis kelautan terdapat dalam Pasal 98 ayat (1), (2), (3) huruf i, ayat (4) serta Pasal 162 ayat (2) huruf e UU Pemerintahan Aceh Tahun 2006, Qanun-qanun Aceh dan peraturan pelaksana di bawahnya, merupakan subjek sarana pembaharuan persekutuan lembaga APS hukum adat laut yang diakui dalam sistem hukum di Indonesia.

Kekuatan hukum lembaga penyelesaian sengketa adat laut Panglima Laôt mengikat para pihak, lembaganya otonom, memahami adat laut dan pesisir, dan diatur oleh produk peraturan perundang-undangan Indonesia. Keputusan berdasarkan aturan hukum adat laut merupakan nilai yang hidup dalam masyarakat dengan menggunakan semua bentuk mekanisme APS meskipun kecenderungannya menggunakan teknik mirip sistem arbitrase sebagaimana sistem hukum di Indonesia. Namun sebenarnya, terdapat perbedaan yang signifikan di antara keduanya. Lembaga penyelesaian sengketa adat laut Panglima Laôt dapat mengisi kekosongan hukum APS keperdataan kelautan, mengurangi tumpukan kasus kelautan di pengadilan perdata, menjadi model APS bisnis kelautan bagi provinsi lainnya serta sebagai pengembangan bentuk hukum APS bidang kelautan di Indonesia.

Penulis menyarankan pembuatan UU tentang Kesatuan Masyarakat Hukum Adat yang merupakan penjabaran langsung dari Pasal 18B ayat (2) UUD 1945. Peraturan 
Sri Walny Rahayu: Lembaga Penyelesaian Sengketa Adat Laut "Panglima Laôt" di Aceh sebagai Bentuk Pengembangan Alternatif Penyelesaian Sengketa dalam Sistem Hukum di Indonesia

perundang-undangan yang mengatur hukum adat dan masyarakat hukum adat yang ada masih tersebar dan parsial. Oleh karena itu dibutuhkan peraturan perundangundangan terutama mengenai pelaksanaan pengelolaan hak ulayat laut yang diperoleh baik secara turun-temurun maupun yang diperoleh melalui mekanisme lain yang sah menurut hukum adat setempat. Saran lainnya yaitu melakukan pendokumentasian terhadap pola penyelesaian sengketa hukum adat khususnya hukum adat laut oleh akademisi, praktisi, lembaga pemerintah, dan swasta melalui riset yang secara laboratoris memperkaya, mengembangkan corak hukum APS produk asli bangsa Indonesia yang merupakan bahan penyusunan hukum APS di Indonesia. Selain itu, dibutuhkan sistem pendukung lembaga APS seperti sosialisasi, keahlian SDM pendukung, institusionalisasi, peran hakim, dan peran pengacara yang membuka kesempatan yang seluas-luasnya proses mediasi sebelum ke pengadilan. Adanya pengaturan lembaga penyelesaian sengketa adat sebagai lembaga APS oleh negara dengan pembatasan yurisdiksi dan pokok sengketa mengadili sebagai upaya mengurangi tumpukan kasus di pengadilan perdata.

\section{Daftar Pustaka}

\section{Buku}

Departemen Pendidikan Nasional, Kamus Besar Bahasa Indonesia Pusat Bahasa, Gramedia Pustaka Utama, Jakarta, 2008.

Eman Suparman, Pilihan Forum Arbitrase dalam Sengketa Komersial untuk Penegakan Keadilan, Tatanusa, Jakarta, 2004.

Hart, H.L.A., The Concept of Law, terjemahan M. Khozim, Nusa Media, Bandung, 2009.

Mochtar Kusumaatmadja, Fungsi dan Perkembangan Hukum dalam Pembangunan Nasional, Binacipta, Bandung, 1976.

\section{Dokumen Lain}

Anonim, Sistem Peradilan Adat dan Lokal di Indonesia, Peluang \& Tantangan, Aliansi Masyarakat Adat Nusantara (AMAN)-Partnership for Governance Reform, Jakarta, 2003.

Darwis dalam Syahrizal, "Hubungan antara Hukum Adat dan Hukum Islam dalam Masalah Kewarisan di Aceh", Program Pascasarjana Universitas Padjajaran Bandung, 2001.

Dinas Perikanan Provinsi Daerah Istimewa Aceh, Keputusan Pertemuan Panglima Laôt/Musyawarah Panglima Laôt se-Provinsi Daerah Istimewa Aceh, Kabupaten Aceh Timur, tanggal 23-25 Januari 1992. 
Sri Walny Rahayu: Lembaga Penyelesaian Sengketa Adat Laut "Panglima Laôt" di Aceh sebagai Bentuk Pengembangan Alternatif Penyelesaian Sengketa dalam Sistem Hukum di Indonesia

Esmi Warassih, "Pemberdayaan Masyarakat dalam Mewujudkan Tujuan Hukum (Proses Penegakan Hukum dan Persoalan Keadilan)" disampaikan pada Pidato Pengukuhan, Fakultas Hukum Universitas Diponegoro, Semarang, 14 April 2001.

Gede Marhaendra Wija Atmaja, "Politik Hukum dalam Pengakuan Kesatuan Masyarakat Hukum Adat dengan Peraturan Daerah", Program Doktor IImu Hukum Universitas Brawijaya, Malang, 2012.

Hukum Online, "Pengadilan Perikanan Belum Efektif”, http://www.hukumonline.com/berita/baca/hol21242/pengadilan-perikananbelum-efektif", diakses 11 April 2013.

Maria Maya Lestari, "Penegakan Hukum Pidana Perikanan di Indonesia Studi Kasus Pengadilan Negeri Medan", Jurnal IImu Hukum, Volume 3 Nomor 2 Tahun 2013, http://www.ejournal.unri.ac.id/index.php/JlH/article/view/1822.html, diakses 11 Februari 2013

Mahkamah Konstitusi Republik Indonesia, "Kedudukan Hukum Kesatuan Masyarakat Hukum Adat dan Keterkaitannya dengan Pemekaran Wilayah", Laporan Diskusi Terbatas, Jakarta, 3 Juni 2008.

\section{Dokumen Hukum}

Undang-Undang Dasar Repblik Indonesia Tahun 1945 dan Penjelasannya.

Undang-Undang Nomor 30 Tahun 1999 tentang Arbitrase dan Alternatif

Penyelesaian Sengketa.

Undang-Undang Nomor 39 Tahun 1999 tentang Hak Asasi Manusia.

Undang-Undang Nomor 44 Tahun 1999 tentang Penyelenggaraan Keistimewaaan

Provinsi Daerah Istimewa Aceh

Undang-Undang Nomor 32 Tahun 2004 tentang Pemerintahan Daerah.

Undang-Undang Nomor 11 Tahun 2006 tentang Pemerintahan Aceh.

Undang-Undang Nomor 17 Tahun 2007 tentang Rencana Pembangunan Jangka Panjang Nasional Tahun 2005-2025 dan Lampirannya.

Undang-Undang Nomor 12 Tahun 2008 tentang Perubahan Kedua atas UndangUndang Nomor 32 Tahun 2004 tentang Pemerintahan Daerah.

Undang-Undang Nomor 45 Tahun 2009 tentang Perubahan atas Undang-Undang Nomor 31 Tahun 2004 tentang Perikanan.

Undang-Undang Nomor 48 Tahun 2009 tentang Kekuasaan Kehakiman.

Undang-Undang Nomor 12 Tahun 2011 tentang Pembentukan Peraturan Perundangundangan.

Undang-Undang Nomor 1 Tahun 2014 tentang Perubahan atas Undang-Undang Nomor 27 Tahun 2007 tentang Pengelolaan Wilayah Pesisir dan Pulau-pulau Kecil. 
Sri Walny Rahayu: Lembaga Penyelesaian Sengketa Adat Laut "Panglima Laôt" di Aceh sebagai Bentuk Pengembangan Alternatif Penyelesaian Sengketa dalam Sistem Hukum di Indonesia

Undang-Undang Nomor 6 Tahun 2014 tentang Desa.

Peraturan Presiden Nomor 5 Tahun 2010 tentang Rencana Pembangunan Jangka Menengah Nasional Tahun 2010-2014.

Peraturan Daerah Nomor 2 Tahun 1990 tentang Pembinaan dan Pengembangan Adat Istiadat di Aceh.

Peraturan Daerah Nomor 7 Tahun 2000 tentang Penyelenggaraan Kehidupan Adat.

Qanun Nomor 16 Tahun 2002 tentang Pengelolaan Sumber Daya Kelautan dan Perikanan.

Qanun Nomor 9 Tahun 2008 tentang Pembinaan Kehidupan Adat dan Adat Istiadat. Qanun Nomor 10 Tahun 2008 tentang Lembaga Adat.

Peraturan Gubernur Aceh Nomor 60 Tahun 2013 tentang Pelaksanaan Penyelesaian Sengketa/Perselisihan Adat dan Istiadat.

Surat Keputusan Gubernur Aceh Nomor 523/315/2000 tentang Pengukuhan Panglima Laôt.

Keputusan Gubernur Provinsi Aceh Nomor 523.11/012/2005 tanggal 8 Maret 2005 tentang Tugas dan Wewenang Panglima Laôt. 